\title{
Increase in pea productivity associated with irrigation management
}

\author{
Osvaldir F Santos ${ }^{1}$; Fernando F Cunha²; Tiago L Taira ${ }^{3}$; Epitácio J Souza ${ }^{4}$; Aguinaldo JF Leal ${ }^{5}$
}

${ }^{1}$ Universidade Estadual Paulista (UNESP), Botucatu-SP, Brazil; osvaldir.feliciano@gmail.com; 2Universidade Federal de Viçosa (UFV), Viçosa-MG, Brazil; fernando.cunha@ufv.br; ${ }^{3}$ Universidade Federal da Grande Dourado (UFGD), Dourados-MS, Brazil; tiago_taira@ hotmail.com; ${ }^{4}$ Universidade Estadual Paulista Júlio de Mesquita Filho (UNESP), Ilha Solteira-SP, Brazil; epitacio_jose@hotmail.com; ${ }^{5}$ Universidade Federal do Triângulo Mineiro (UFTM), Iturama-MG, Brazil; aguinaldo.leal@uftm.edu.br

\begin{abstract}
Proper irrigation management is crucial to obtain high yields of pea, since its cultivation is recommended in cold and dry seasons. Taking into account the great genetic diversity, we considered necessary to evaluate cultivars which best adapt to the intrinsic conditions of Cerrado Region, as it presents low fertility soil, long dry period in the winter, drought periods (veranicos) in rainy season, mainly in January and February (summer). Thus, the aim of this study was to evaluate adaptability of green-pea cultivars under different irrigation depths in Northeast Region of state of Mato Grosso do Sul. The experiment was installed in a split plot scheme, with four irrigation depths $[50,75,100$ and $125 \%$ of crop evapotranspiration $(\mathrm{ETC})]$ and at subplots, four pea cultivars (Forró, Frevo, Pagode and Samba) in a randomized block design with three replications. Pod length, number and mass of grains per pod, number of pods per plant, plant length, productivity and efficiency of water use were evaluated. Excess water supply (water stress) or shortage (water deficit) can cause decrease in the productivity of pea crop for green grains, considering replacement of $114.81 \%$ of Etc, the most recommended for the crop. Cultivar Forró, showed the best productive performance in relation to other cultivars, in the climatic conditions of Southern Cerrado (Mato Grosso do Sul, Brazil).
\end{abstract}

Keywords: Water deficit; Pisum sativum, edaphoclimatic adaptability.

\section{RESUMO}

Aumento da produtividade de ervilha associado ao manejo da irrigação

O manejo adequado da irrigação é crucial para obtenção de elevados rendimentos da ervilha, pois seu cultivo é recomendado em épocas frias e secas. Considerando a grande diversidade de materiais genéticos, há necessidade de avaliar cultivares que melhor se adaptam às condições intrínsecas da região do cerrado pois os mesmos apresentam solos de baixa fertilidade, grande período seco no inverno, ocorrência de veranicos no período chuvoso, principalmente nos meses de janeiro e fevereiro (verão). Diante disto, objetivou-se avaliar a adaptabilidade de cultivares de ervilha-verde em diferentes lâminas de irrigação na região nordeste do estado de Mato Grosso do Sul. O experimento foi conduzido em esquema de parcelas subdivididas, tendo nas parcelas quatro lâminas de irrigação [50, 75, 100 e 125\% da evapotranspiração da cultura (ETc)] e nas subparcelas quatro cultivares de ervilha (Forró, Frevo, Pagode e Samba) no delineamento em blocos casualizados, com três repetições. Foram avaliados o comprimento de vagens, número e massa de grãos por vagem, número de vagens por planta, comprimento da planta, produtividade e eficiência do uso da água. O suprimento hídrico quando em excesso (estresse hídrico) ou em falta (déficit hídrico) pode provocar queda na produtividade da cultura de ervilha para grãos verdes, sendo a lâmina com reposição de $114,81 \%$ da ETc a mais recomendada para a cultura. A cultivar Forró, apresentou melhor desempenho produtivo em relação às demais cultivares, nas condições climáticas da região do Cerrado sul-mato-grossense.

Palavras-chave: Pisum sativum, déficit hídrico; adaptabilidade edafoclimática.

\section{Received on September 19, 2017; accepted on March 2, 2018}

$\mathrm{V}$ egetable cultivation requires high investment per hectare and this is considered one of the agricultural activities which presents the greatest cost, with the highest level of financial risk. On the other hand, this activity determines the highest net income per hectare (Gassi et al., 2009). Brazilian economy has experienced an accelerated growth of vegetable cultivation in the process of agro-industrialization, considering some crops as being very important in this scenery (Vilela \& Macedo, 2000).

The state of Mato Grosso do Sul is not a traditional vegetable-growing area, prevailing the cultivation of soybean and corn, and beef cattle raising (Gassi et al., 2009). However, considering agricultural, economic and nutritional terms, peas (Pisum sativum) are considered a feasible alternative to increase the producers' income. Taking into consideration that, according Giordano (1997), different from other vegetables, peas have a relatively low production cost, and the crop can be an excellent option to be grown in winter, during the low production season of major crops. 
In Cerrado conditions, several foreign or Brazilian cultivars achieve satisfactory grain yield and quality, both for dry and green grains (Nascimento \& Giordano, 1994). Further studies on productive performance of more modern cultivars are necessary, since literature on agronomic and economic performance of this crop is still outdated and scarce.

Choosing pea cultivars, which are most adapted to climate and type of soil of a region, allows an increase in crop productivity. Through continuous selection over time, pea allowed the development of several cultivars adapted to different soil and climatic conditions (Smýkal et al., 2012), which was necessary due to constant threat of biotic or abiotic stresses on the crop (Jain et al., 2014).

Besides choosing the appropriate cultivar, the irrigation system necessary to supply crop water requirements is important to achieve high productivity, considering that vegetables, generally, need an appropriate water supply during the whole development cycle (Marouelli \& Guimarães, 2006).

Lack of researches, in order to determine the optimum water depth for crops of the region results, in an inappropriate water management, which many times can be harmful to pea production. According to Duzdemir et al. (2009), the pea is a crop which is very sensitive to water stress. Giordano (1997) also highlights that excess of water can affect plant development, due to lodging, an increase of fungal diseases and uneven maturity.

Given the above, the aim of this study was to evaluate the adaptability of green pea cultivars under different water depths in Northeast Region of the state of Mato Grosso do Sul.

\section{MATERIAL AND METHODS}

The experiment was carried out at Experimental Area of Universidade Federal de Mato Grosso do Sul, Campus Chapadão do Sul, located in the municipality of Chapadão do Sul-MS (1847'39'S, 52\%37'22”W, altitude $820 \mathrm{~m})$. The climate of the region is humid tropical, maximum and minimum temperatures of 33.2 and $3.3^{\circ} \mathrm{C}$, respectively; maximum and minimum relative humidity 99 and $11 \%$ and rainfall of $167.8 \mathrm{~mm}$ during the experimental period. These data were collected at meteorological station of National Institute of Meteorology (INMET) installed at a distance of 3.84 $\mathrm{km}$, measuring $12 \mathrm{~m}$ between horizontal and vertical distances, respectively. Rainfall data were collected in the experimental area.

Soil was classified as typic distrophic Red Latosol, clayey texture (EMBRAPA, 2013), which was originally occupied by Cerrado vegetation and cultivated with annual crops for several years. Chemical properties in the 0 to $20 \mathrm{~cm}$ layer are: $\mathrm{P}_{\text {mehlich }}=8.0 \mathrm{mg} \mathrm{dm}^{-3}$; Organic matter $=$ $31.1 \mathrm{~g} \mathrm{dm}^{-3} ; \mathrm{pH}_{(\mathrm{CaCl} 2)}=4.8 ; \mathrm{K}^{+}=0.38$; $\mathrm{Ca}^{2+}=2.80 ; \mathrm{Mg}^{+2}=1.10$; and $\mathrm{H}+\mathrm{Al}=$

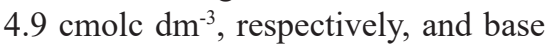
saturation, $46.6 \%$.

Soil water contents equivalent to the field capacity and permanent wilting point of the plant were obtained through soil water retention curves using Richards extractor (Richards, 1949). Water contents equivalent to field capacity for 0-0.2 and 0.2-0.4 m layers were 0.2662 and $0.2680 \mathrm{~m}^{3} \mathrm{~m}^{-3}$, respectively. Whereas water content equivalent to the permanent wilting point obtained in these same layers were 0.1878 and $0.1951 \mathrm{~m}^{3}$ $\mathrm{m}^{-3}$ and soil densities, determined by the volumetric ring method, were 1.2208 and $1.1954 \mathrm{~g} \mathrm{dm}^{-3}$.

The experiment was arranged in a split plot scheme, plots consisting of four water depths [50, 75, 100 and $125 \%$ of crop evapotranspiration (Etc)] and subplots of four pea cultivars (Forró, Frevo, Pagode and Samba). The experimental design was randomized blocks, with three replicates. The experimental units consisted of 2-m length plots ( $0.4 \mathrm{~m}$ border) and $1.2-\mathrm{m}$ width plots $(0.2 \mathrm{~m}$ border $)$, resulting in a total area of $2.4 \mathrm{~m}^{2}$ and useful area of $1.6 \mathrm{~m}^{2}$.

Soil preparation consisted of plowing and, then, harrowing. Acidity was corrected according to Souza \& Lobato (2004), applying $1.46 \mathrm{t} \mathrm{ha}^{-1}$ of limestone, raising base saturation to $60 \%$. Sowing fertilization and top- dressing were performed based on soil chemical analysis and according to Giordano's recommendation (1997) for pea crop. Sowing fertilization consisted of $750 \mathrm{~kg} \mathrm{ha}^{-1}$ of simple superphosphate $\left(20 \% \mathrm{P}_{2} \mathrm{O}_{5}\right), 33.5 \mathrm{~kg} \mathrm{ha}^{-1}$ of potassium chloride $\left(60 \% \mathrm{~K}_{2} \mathrm{O}\right), 40 \mathrm{~kg} \mathrm{ha}^{-1}$ of urea $(40 \% \mathrm{~N})$ and $23.52 \mathrm{~kg} \mathrm{ha}^{-1}$ of boric acid (17\% B); and top-dressing was performed at 51 days after emergence (DAE) at flowering beginning, using $107 \mathrm{~kg} \mathrm{ha}^{-1}$ of calcium nitrate.

Seeds were treated with Iprodione (40g i.a./100 kg seeds) and Carboxine (48g i.a./100 kg seeds) + Tiram (48 g i.a./100 kg seeds). Sowing was performed on May 29, 2013, in spacing of $0.2 \mathrm{~m}$ between lines and two seeds in each $0.0625 \mathrm{~m}$, afterwards, thinning was carried out, leaving 96 plants $\mathrm{m}^{-2}$. Plots consisted of 6 rows, 2-m length. During the experiment, phytosanitary treatments were done using insecticide imidacloprid (75 mL i.a. ha $\left.{ }^{-1}\right)+$ BetaCyfluthrin (9.375 mLi.a. ha-1), applying herbicides Fluazifop-P-Butyl (370 g i.a. ha $^{-1}$ ) and Bentazone (720 g i.a. ha ${ }^{-1}$ ).

Water was supplied through a drip irrigation system, consisting of a 20-meter high reservoir, 50-mm diameter PVC pipeline, main pipes of 32-mm diameter PVC and 16-mm inner diameter dripper lateral lines (Petroisa drip hose). Emitters were spaced at 0.2 $\mathrm{m}$, using an emitter flow rate of 2.09 $\mathrm{L} \mathrm{h}^{-1}$, and Christiansen Uniformity Coefficient (CUC) of 94\%, one lateral line for each double row of plants.

Before crop implantation, the experimental area received a 3 -hour irrigation, in order to increase the soil water availability to the field capacity. Water was replaced according to the crop needs in relation to the crop evapotranspiration, maintaining soil moisture content always at its field capacity.

Actual irrigation required for $100 \%$ of crop evapotranspiration was performed in relation to the parameters of the climate, plant and soil characteristics (equation 1), representing actual irrigation required in the system.

$$
\mathrm{IRN}_{\mathrm{LOC}}=\sum_{\text {dia }_{1}}^{i} E T_{0} x K_{c} x K_{5} x K_{L}-P_{E}
$$

in which: $\operatorname{IRN}_{\mathrm{LOC}}=$ actual irrigation required in localized systems $(\mathrm{mm})$; 
$\mathrm{ET}_{0}=$ reference evapotranspiration $\left(\mathrm{mm} \mathrm{day}{ }^{-1}\right) ; \mathrm{K}_{\mathrm{C}}=$ crop coefficient (dimensionless); $\mathrm{K}_{\mathrm{S}}=$ coefficient of soil moisture (dimensionless); $\mathrm{K}_{\mathrm{L}}=$ location coefficient (dimensionless); and $\mathrm{P}_{\mathrm{E}}=$ effective rainfall during the period (mm).

Effective rainfall was the one which directly satisfies the crop (Bernardo et al., 2008), considering the necessary water to increase the water content at the time of rainfall up to the water content equivalent to the field capacity. Reference evapotranspiration (ETo) was calculated using Penman-Monteith methodology (Allen et al., 1998). Crop coefficients $(\mathrm{Kc})$ were 0.6 and 1.10 for stages I and III, respectively. For stage II, the authors used linear weighting between end of stage I and beginning of stage III. Stages I and II lasted 19 and 27 days, respectively, and stage III from $46^{\circ}$ day up to the harvest, during 35 days for cultivars Forró and Frevo, 36 days for Pagode and 40 days for Samba. Coefficient of soil moisture (Ks) and location coefficient $\left(\mathrm{K}_{\mathrm{L}}\right)$ were established according to Bernardo et al. (2008).

Pods were harvested manually from the $83^{\circ} \mathrm{DAE}$ on, after grain filling in all pods. These pods were kept in paper bags and taken to laboratory for analysis. The evaluated traits were: a) pod length, determined using five pods by replication, measuring the extension from one end to the other; b) number of grains per pod; c) mass of grains per pod; d) number of pods per plant; e) plant length (from soil level up to upper edge of the plants, measuring five plants by replication); f) productivity (determined by the grain collection of the plants in the 2 central rows of each replication, and then productivity was extrapolated into $\mathrm{kg}$ $\mathrm{ha}^{-1}$ ); g) WUE (water use efficiency in $\mathrm{kg} \mathrm{m}^{-3}$, determined by the ratio between productivity and quantity of water used during crop cycle).

For statistical analysis, obtained data were submitted to variance and regression analyses. Averages (pea cultivars) were compared using Tukey test at $5 \%$ probability. For quantitative factor (water irrigation depths), the models were chosen based on significance of regression coefficients.

\section{RESULTS AND DISCUSSION}

Considering the 92 days required to complete the pea crop cycle, the authors noticed that plants had to be irrigated during 70 days to keep the water requirements of the crop under favorable conditions for its development. Water depth values applied to the treatments designed to replace 50,75, 100 and $125 \%$ of ETc, were 109.8, 164.6, 219.5 and $274.4 \mathrm{~mm}$ respectively, and effective rainfall observed was 39.0 , 28.4, 16.3 and $16.3 \mathrm{~mm}$.

Effective rainfall was superior on the water depth of $50 \%$ Etc and, with the increase of water depth, the authors could notice a decrease in this value up to the water depth of $100 \%$ Etc. Overall, from $167.8 \mathrm{~mm}$ of total rainfall, distributed in 8 events, only $23.4 \%$ was used by the water depth of $50 \%$ and the highest water depth showed an use of only $9.71 \%$.

Taking into consideration that the effective rainfall is taken as the fraction of total rainfall that the crop uses to meet its evapotranspirometric demand (Bernardo et al., 2008), these results may be related to water deficit resulting from water depths lesser than ETc. It

Table 1. Average values of plant length, productivity and water use efficiency in relation to different pea cultivars. Chapadão do Sul, UFMS, 2013.

\begin{tabular}{|c|c|c|c|c|c|}
\hline \multirow{2}{*}{ Variable } & \multirow{2}{*}{ Cultivars } & \multicolumn{4}{|c|}{ Irrigation water depth (\% ETc) } \\
\hline & & 50 & 75 & 100 & 125 \\
\hline \multirow{4}{*}{ Plant length $(\mathrm{cm})$} & Forró & \multicolumn{4}{|c|}{$60.60 \mathrm{a}$} \\
\hline & Frevo & \multicolumn{4}{|c|}{$42.83 \mathrm{bc}$} \\
\hline & Pagode & \multicolumn{4}{|c|}{$50.08 \mathrm{~b}$} \\
\hline & Samba & \multicolumn{4}{|c|}{$38.75 \mathrm{c}$} \\
\hline \multirow{4}{*}{ Productivity $\left(\mathrm{t} \mathrm{ha}^{-1}\right)$} & Forró & \multicolumn{4}{|c|}{$5.49 \mathrm{a}$} \\
\hline & Frevo & \multicolumn{4}{|c|}{$2.39 \mathrm{c}$} \\
\hline & Pagode & \multicolumn{4}{|c|}{$3.72 \mathrm{~b}$} \\
\hline & Samba & \multicolumn{4}{|c|}{$3.13 \mathrm{~b}$} \\
\hline \multirow{4}{*}{$\begin{array}{l}\text { Water use efficiency } \\
\left(\mathrm{kg} \mathrm{m}^{-3}\right)\end{array}$} & Forró & $3.06 \mathrm{a}$ & $2.68 \mathrm{a}$ & $2.58 \mathrm{a}$ & $2.11 \mathrm{a}$ \\
\hline & Frevo & $0.80 \mathrm{c}$ & $1.26 \mathrm{~b}$ & $1.27 \mathrm{~b}$ & $1.01 \mathrm{~b}$ \\
\hline & Pagode & $1.99 \mathrm{~b}$ & $1.76 \mathrm{~b}$ & $1.78 \mathrm{~b}$ & $1.49 \mathrm{ab}$ \\
\hline & Samba & $1.00 \mathrm{c}$ & $1.83 \mathrm{~b}$ & $1.59 \mathrm{~b}$ & $1.28 \mathrm{~b}$ \\
\hline
\end{tabular}

Averages followed by same letters in columns do not differ statistically among them, according to Tukey test $(\mathrm{p}<0.05)$.

means that soil was not in its maximum storage capacity; thus the quantity of water which infiltrates into soil (from the rainfall) and ends up being retained, is greater under these conditions.

However, in excess-water environments (water depth values higher than ETc), due to high frequency of irrigation used in this study, the occurrence of rainfall exceeded soil water storage capacity. Consequently, superficial runoff and/or deep percolation of the water was verified, which has considerably reduced effective rainfall.

Considering all evaluated variables only WUE showed interaction between cultivars and water depths. Any significance was noticed in relation to difference for pod length, number of grains per pod, grain mass per pod and number of pod per plant in the genetic materials used in the study. However, in all evaluated variables, the absence of water deficit resulted in better production components, which was not verified only for WUE (Figures 1. 2 and 3 ).

Increasing water depth, an increase in pod length was observed (Figure $1 \mathrm{~A})$, and higher values $(6.97 \mathrm{~cm})$ were obtained with a water replacement of $125 \%$ Etc. However, growing pea plants in environments with low availability of water $(50 \%$ of ETc $)$, results in 
a reduction in pod length, $14.3 \%$ approximately. According to Taiz \& Zeiger (2009), this is due to the fact that among production components, pod length shows less sensitivity to water stress, since in this condition the most assimilates are directed to the fruits. Nascimento et al. (2004) and Ramos et al. (2014), studying beans, also verified reduction in pod length in water-deficit environments.

Generally, number of grains per pod is directly related to pod length, since the larger the number of grains, the longer the pod length. This fact explains similar behavior observed in these production components (Figures $1 \mathrm{~A}$ and 1B). The water depth which maximizes this variable was $125 \%$ ETc, resulting in 7.12 grains, however, this component showed low sensitivity to water availability, since a reduction in only $12.8 \%$ was noticed, when the plant was submitted to water-deficit environments (50\% ETc) (Figure 1B).

In water-deficit situations, mass of grains per pod was the production component which was most affected, $33.5 \%$ from the lower $(50 \%$ ETc) to the higher (125\% ETc) water depth used (figure 1C). This fact, according to Borrmann (2009), is due to the reduction of the enzyme activities responsible for chlorophyll degradation, in relation to the low water availability, mainly during the grain filling phase, which results in high content of green and empty grains.

Number of pods per plant also showed an increase as higher contents of water in the soil were available (Figure 2A), where water depth with water replacement of $125 \%$ of Etc provided 6.6 pods per plant. Vieira et al. (2007) reported that pea yield is greatly impaired if water deficit occurs between the beginning of flowering and pod filling phase, since no flower setting occurs and, consequently, no pod formation either. This fact could explain the reduction of the number of pods, up to $31.6 \%$, when the water depth with replacement of $50 \%$ of ETc is applied.

Cultivar Forró showed the highest plant length $(61 \mathrm{~cm})$ in relation to the others, a difference about $36.6 \%$ longer than Cultivar Samba (Table 1). With the reduction of soil water availability, a

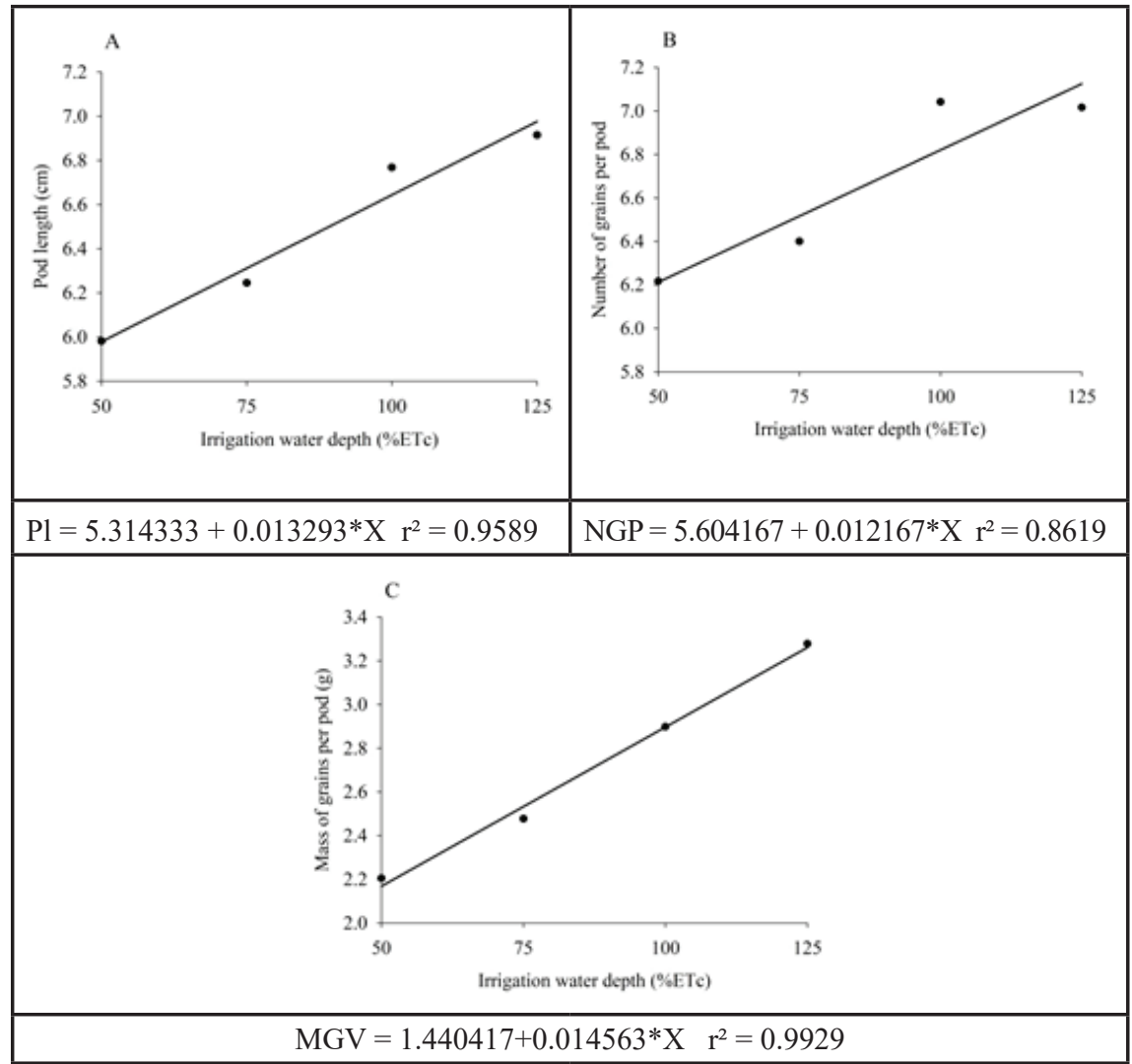

Figure 1. Average estimate of pod length (A), number of grains per pod (B) and mass of grains per pod (C) of peas submitted to different irrigation depths. Chapadão do Sul, UFMS, 2013.

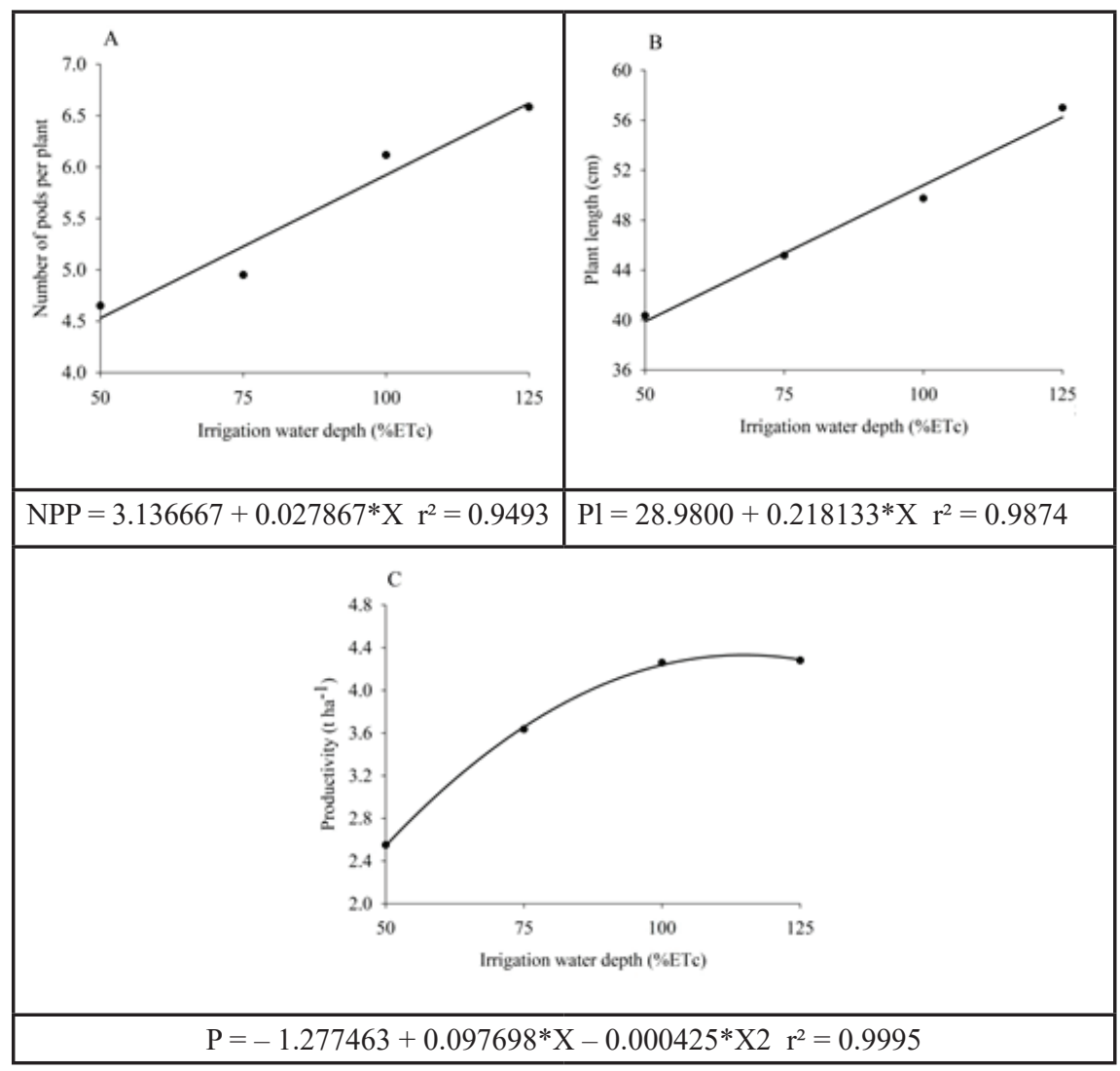

Figure 2. Average estimate of pods per plant (A), plant length (B) and productivity (C) of peas submitted to different irrigation depths. Chapadão do Sul, UFMS, 2013. 


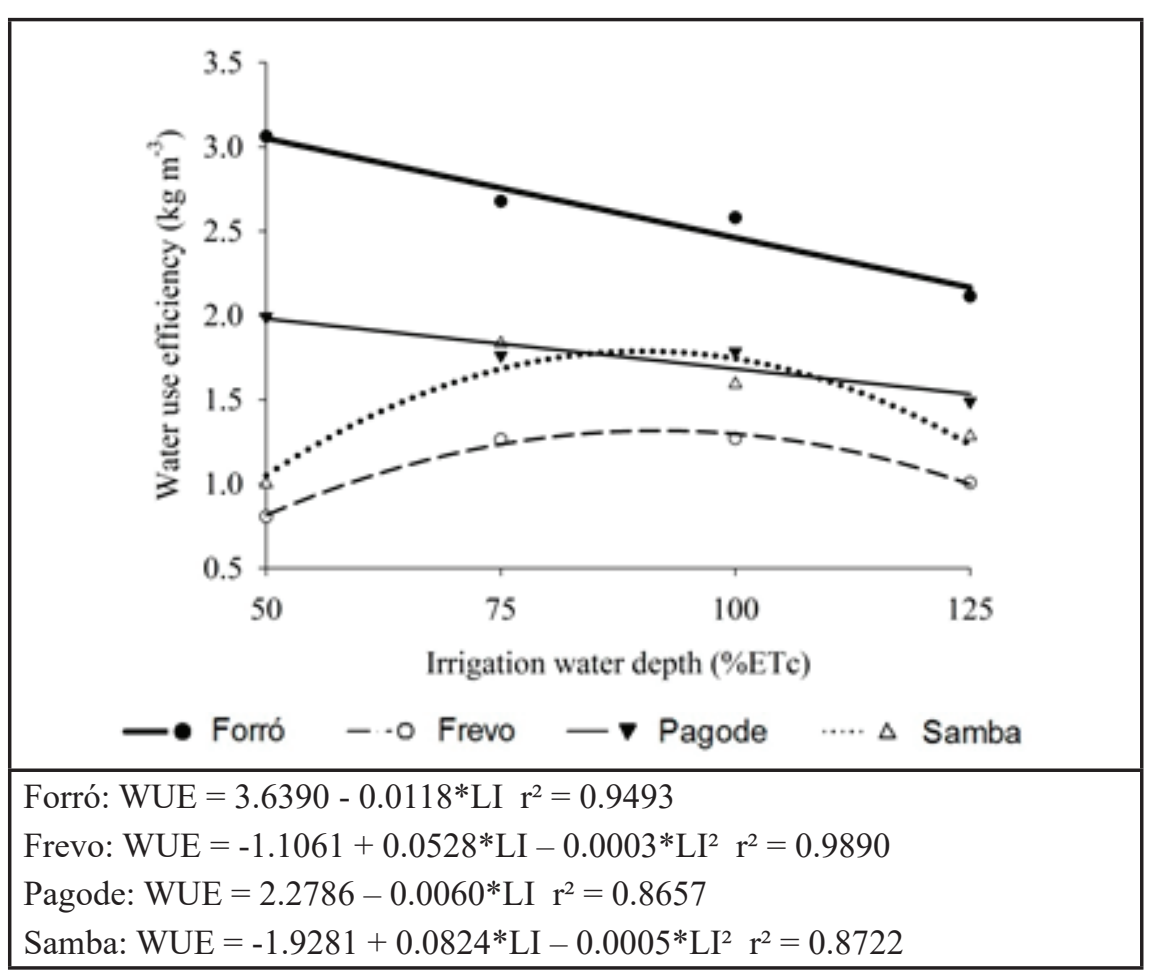

Figure 3. Estimate of water use efficiency of different pea cultivars, submitted to different irrigation water depths. Chapadão do Sul, UFMS, 2013.

decrease in plant length could be noticed (Figure 2B); According to Fioreze \& Guimarães (2015), this is explained by the fact that plants submitted to water deficit tend to reduce turgidity of cells, which then affect cell expansion and consequently the elongation of the plant.

Higher productivity values were obtained using cultivar Forró (5.49 $\mathrm{t} \mathrm{ha}^{-1}$ ) (Table 1) however, according Embrapa (2014) the pea cultivars Forró, Frevo, Pagode and Samba, can reach productivities up to $7 \mathrm{tha}^{-1}$. In irrigated areas, in Cerrado region, Cardoso et al. (2012) obtained approximately $10 \mathrm{t} \mathrm{ha}^{-1}$ of green grains of peas using cultivar Utrillo.

Nevertheless, in this study a great variation of productivity among cultivars could be noticed (Table 1), the difference reached $56.49 \%$ between the cultivar with the best (Forró) and the worst performance (Frevo). These results can be associated to the final stand of plants, since among the evaluated production components of the genetic material studied, no statistical difference was verified (Table 1) and it is known that the components are directly related to productivity.
The presence of Rhizoctonia solani in the experimental area, during the crop development, may have influenced the reduction of initial stand of plants, according to what was highlighted by Giordano (1997). Although no evaluation of disease severity was performed, a higher rate of stalk rot was observed visually in the cultivars, which later caused plant bending and consequently its death. Being soil fungi, they are invariably difficult to control economically (Costa, 2001). As a result, no control measures were adopted.

Increasing water availability for plants, productivity increased too (Figure 2C), up to water depth with replacement of $114.81 \%$ of Etc, resulting in an average productivity of $4.33 \mathrm{tha}^{-1}$, and consequently a decrease after this value. The low productivity values observed for water deficit and saturation can be explained because water deficit alters the plant behavior (De Wit, 1978). This author states that, irreversibility will depend on the genotype, duration, severity and plant growth stage. Water excess affects the root and shoot development, and also reduces nitrogen fixation by root system, as it reduces oxygen in nodules with a consequent reduction in the number of nodules on a root system (De Wit, 1978).

Increase of water availability for plants provided a linear reduction in WUE of cultivars Forró and Pagode (Figure 3), in which the water depth with replacement of $50 \%$ of Etc showed better results $\left(3.049 \mathrm{~kg} \mathrm{~m}^{-3}\right.$ and 1.979 $\mathrm{kg} \mathrm{m}^{-3}$ of water, respectively). These values were similar to the ones obtained by Oliveira et al. (2011) and Souza et al. (2015), who observed maximum values of WUE when the plant showed water deficit, with a decrease as higher water depths were applied. Cultivars Frevo and Samba showed WUE with quadratic behavior, in which the water depths which maximized this efficiency were estimated in $88 \%$ and $82.4 \%$ of crop evaporation replacement, resulting in $1.22 \mathrm{~kg} \mathrm{~m}^{-3}$ and $1.47 \mathrm{~kg} \mathrm{~m}^{-3}$ of water density, respectively.

Oliveira et al. (2011) highlight that the concept of water use efficiency is relative, it means, higher efficiency does not mean higher productivity. This fact can better been noticed when productivity graphics (Figure 2C) and WUE (Figure 3) are compared. Thus, higher water-use efficiency would represent less impact on the environment and would reduce production costs, considering economy of water or economy in the matrix of energy.

According to the results obtained in this study, cultivar Forró shows best productivity performance under soil and climatic conditions of the Northeast region of the state of Mato Grosso do Sul, highlighting that when water supply is in excess (water stress) or insufficient (water deficit), pea productivity for green grains can decrease.

\section{ACKNOWLEDGMENTS}

To Embrapa Hortaliças for providing pea seeds and to Petroisa Irrigação for providing drip tape and other connectors.

\section{REFERENCES}

ALLEN, RG; PEREIRA, LS; RAES, D; SMITH, 
M. 1998. Crop evapotranspiration: Guidelines for computing crop water requirements. Roma: FAO Irrigation and Drainage Paper 56. 300p.

BERNARDO, S; SOARES, AA; MANTOVANI, EC. 2008. Manual de irrigação. 8. ed. Viçosa: Editora UFV. 625p.

BORRMANN, D. 2009. Efeito do déficit hídrico em características químicas e bioquímicas da soja e na degradação da clorofila, com ênfase na formação de metabolitos incolores. São Paulo: USP, Faculdade de Ciências Farmacêuticas. 107p (Tese Doutorado).

CARDOSO, ED; HAGA, IK; BINOTTI, FFS; VALERIO FILHO, WV; NOGUEIRA, DC. 2012. Doses de zinco e nitrogênio na produtividade e qualidade de grãos de ervilha. Pesquisa Agropecuária Tropical 42: 263-271.

COSTA, JLS. 2001. Controle de podridões radiculares na cultura do feijoeiro: Eficácia da aplicação de fungicidas no sulco de plantio. Santo Antônio de Goiás: Embrapa, Documentos 118. 18p.

DE WIT, MC. 1978. Metabolic adaptation to anoxia. In: HOOK, DD; CRAWFORD, EMM. (eds). Plant life in anaerobic environments. Michigan: Ann Arbor Science. p.333-350.

DUZDEMIR, O; KURUNC, A; UNLUKARA, A. 2009. Response of pea (Pisum sativum) to salinity and irrigation water regime. Bulgarian Journal of Agricultural Science 15: 400-409.

EMBRAPA. 2013. Sistema brasileiro de classificação de solos. 3.ed. Brasília: EMBRAPA. 353p.

EMBRAPA. 2014. Cultivares da Embrapa Hortaliças (1981-2013). Brasília: EMBRAPA.
$182 \mathrm{p}$.

FIOREZE, SL; GUIMARÃES, VF. 2015. Manutenção do status hídrico de plantas de soja induzida por etil-trinexapac. Scientia Agraria Paranaensis 14: 166-172.

GASSI, RP; ZÁRATE, NAH; VIEIRA, MC; GOMES, HE; MUNARIN, EEO; RECH, J 2009. Espaçamentos entre plantas e número de fileiras no canteiro na produção da ervilha. Horticultura Brasileira 27: 549-552.

GIORDANO, LB. 1997. Cultivo da Ervilha (Pisum sativum L.).Brasília: Embrapa Hortaliças. 20p.

JAIN, S; KUMAR, A; MAMIDI, S; MCPHEE, K. 2014. Genetic diversity and population structure among pea (Pisum sativum L.) cultivars as revealed by simple sequence repeat and novel genic markers. Molecular biotechnology 56: 925 -938.

MAROUELLI, WA; GUIMARÃES, TG. 2006. Irrigação na cultura da batata. Itapetininga: Associação Brasileira da Batata. 66p.

NASCIMENTO, WM; GIORDANO, LB. 1994. Avaliação de linhagens de ervilha para enlatamento e congelamento. Horticultura Brasileira 12: 181-183.

NASCIMENTO, JT; PEDROSA, MB; TAVARES SOBRINHO, J. 2004. Efeito da variação de níveis de água disponível no solo sobre o crescimento e produção de feijão-caupi, vagens e grãos verdes. Horticultura Brasileira 22: 174-177.

OLIVEIRA, EC; CARVALHO, JA; REZENDE, FC; FREITAS, WA. 2011. Viabilidade técnica e econômica da produção de ervilha (Pisum sativum L.) cultivada sob diferentes lâminas de irrigação. Engenharia Agrícola 31: 324-333.

RAMOS, HMM; BASTOS, EA; CARDOSO, MJ; RIBEIRO, VQ; NASCIMENTO, FN. 2014. Produtividade de grãos verdes do feijão-caupi sob diferentes regimes hídricos. Engenharia Agrícola 34: 683-694.

RICHARDS, LA. 1949. Methods of measuring soil moisture tension. Soil Science of American Journal 68: 95-112.

SOUZA, DMG; LOBATO, E. 2004. Cerrado correção do solo e adubação. 2 ed. Brasília: EMBRAPA. 416p.

SOUZA, EJ; CUNHA, FF; MAGALHÃES, FF; SILVA, TR; SANTOS, OF. 2015. Effect of irrigation and nitrogen fertilization on agronomic traits of sweet corn. Pesquisa Agropecuária Tropical 45: 282-290.

SMÝKAL, P; AUBERT, G; BURSTIN, J; COYNE, CJ; ELLIS, NTH; FLAVELL, AJ; FORD, R; HÝBL, M; MACAS, J; NEUMANN, P; MCPHEE, KE; REDDEN, RJ; RUBIALES, D; WELLER, JL; WARKENTIN, TD. 2012. Pea (Pisum sativum L.) in the genomic era. Agronomy 2: 74-115.

TAIZ, L; ZEIGER, E. 2009. Fisiologia vegetal. Porto Alegre: Artmed. 819p.

VIEIRA, RF; PINTO, CMF; VIEIRA, C. 2007. Ervilha (Pisum sativum L.). In: PAULA JÚNIOR, TJ; VENZON, M. (eds). 101Culturas: Manual de Tecnologia Agrícola. Minas Gerais: EPAMIG. p.317-320.

VILELA, NJ; MACEDO, MMC. 2000. Fluxo de poder no agronegócio: o caso das hortaliças. Horticultura Brasileira 18: 88-94. 